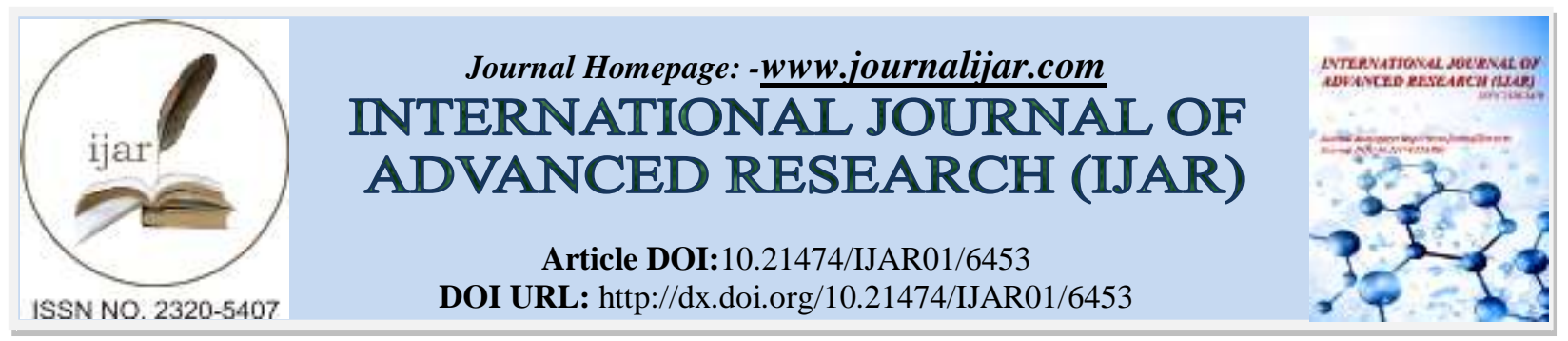

RESEARCH ARTICLE

\title{
PRELIMINARY ANALYSING OF PLANT DIVERSITY OF HIGH ALTITUDE AREA OF ALBAHA REGION, SAUDI ARABIA.
}

\author{
Abdulrahman Al-Zandi ${ }^{1}$, Abdul Wali Al-Khulaidi ${ }^{1,2}$ and Nageeb A. AL-Sagheer ${ }^{1}$. \\ 1. Department of Biology, Al Baha University, Saudi Arabia. \\ 2. Agricultural Research and Extension Authority, Yemen.
}

\section{Manuscript Info}

Manuscript History

Received: 05 December 2017

Final Accepted: 07 January 2018

Published: February 2018

Keywords:-

Floristic. Diversity. Frequency. IVI index. Al Baha. Saudi Arabia.

\section{Abstract}

The study on the floristic analysis and plant diversity was carried out during the years 2014 and 2016 covering the high altitudinal plateau between 1900 to 2475 mater above sea level (m. a. s. 1.) of Al Baha region, Saudi Arabia. This attempt was made, to document the density; frequency and diversity of plant species existing in different land forms, to identify the priorities of conservation and rehabilitation for the least occurrence plant species and Juniperus procera and Acacia origena habitats in the future plan.

Random quadrat methods of $25 * 25 \mathrm{~m}$ were laid out in various parts of the region to reach the total of 73 sample plots. The data was analyzed using different ecological indices and tools. The out come of the analyzed data showed a total of 187 plant species belonging to 147 genera and 67 families, in which 3 are endemic to Arabian Peninsula and one is endemic to Saudi Arabia. Hyparrhenia hirta, Achillea biebersteinii, Cynodon dactylon, Themeda triandra Juniperus procera and Eragrostis papposa have the highest density per hectare with a value of 226, 176, 167, 134, 116 and 107 respectively. Frequency of plant species showed different trend of plant arrangement in different sample plots unlike the density. For instance Juniperus procera, Acacia origena, Dodonaea viscose, Psiadia punctulata and Sageretia thea have more frequency with a value of $0.86,0.67,0.47,0.45$ and 0.44 respectively. The dominant vegetation structure is a woodland dominated by Juniperus procera and Acacia origena and grassland dominated by Hyparrhenia hirta and Themeda triandra. Average tree cover is $25 \%$, shrub cover is $17 \%$ and herbaceous cover is $36 \%$ with an average of $77 \%$ vegetation cover.

Copy Right, IJAR, 2018,. All rights reserved.

\section{Introduction:-}

Al-Baha highlands are the habitats of highly significant plant diversity of Saudi Arabia and the Arabian Peninsula. In the region plateaus and mountains with scattered hills are the dominant characteristics of land forms and their vegetation compositions are highly influenced by the occurrences of intensive seasonal fogs. Harvesting of moisture from the fog may contribute to the occurrence of diverse plant species in the area. Similarly in some highland and arid regions of Asia and South America thick or rather open fog forests are well supported through the trees special 
ability to the trees to harvest moisture from the fog or passing clouds [1-3] .

In the Arabian Peninsula, Juniper woodlands are well developed and widely occur in southern mountains of Saudi Arabia, Jabal Eraf (Yemen) and Jabal Al Akhdhar north of Oman. It is well adapted to arid climate conditions with annual rainfall of 300-600 mm [4-6]. The Juniper woodland is the most prominent component of woodlands or as co-dominant with other trees species at or above $1600 \mathrm{~m}$ in Asir Mountains [1,2] and in Al-Baha highlands of Saudi Arabia. Juniper woodlands are important because many species grow associated with species having moisture harvesting abilities from fog and passing clouds.

Moreover, because of the existing of Juniperus procera woodland with abandoned agricultural farm lands and plateaus dominated by Acacia origena community make the study area is made as one of the richest plant diversity in the region. Within high land areas, gradients in elevation are well known to create varied climates with subsequent soil differentiation that contributes to the diversification of plant species [7, 8]. All such phenomenon makes the area as one of hot spots to study the species diversity in the region.

This strip of Al-Baha highland plateau, stretched from an elevation of 2000-2400 m above sea level has been occupied and used for farming, animal husbandry and extensive construction by humans for long periods. Moreover, the threat of exotic species to natural habitats obviously, resulted in the decrease of the number of native species in their habitat and replaced them with the invasive widespread species such as Nicotiana glauca. Thus, this causes regional homogenization of ecosystems. This species forms dense stands that can destroy the habitats by encroaching native vegetation that serves as food sources or habitat for wildlife.

Frequency is defined as the number of times at which a plant species occurs within a given numbers of sampling sites of uniform size placed across a given vegetation cover [9-10]. It is also generally expressed as a percentage of total placements [11]. So, frequency is useful information for monitoring vegetation changes over time at the same locations or for comparisons of different locations. Besides species frequency; plant density and species diversity are important information and have been used by ecologist to evaluate plant species in different ecosystems [12] as well as to determine species richness and evenness within a plant community [13]. Moreover, species diversity has been considered as a factor alongside species composition, disturbance, soil type and climate that influence ecosystem functioning [14].

Many studies have investigated species richness variations along elevation gradient across habits and taxa [15-18]. Such species have also been investigated as part of efforts to understand the ecosystem effects on biodiversity and its conservation $[17,19]$. Many researchers have explored altitudinal biodiversity patterns of plants and reported that altitude plays a great role in regulating species richness patterns [20-22]. Moreover, Qian et al, [23] reported that altitude plays stronger role in maintaining large-scale species richness in China than in any other area because China encompasses the world's widest range of altitudes. So in this study frequency and species diversity across elevation gradient will be considered as important parameters in the analysis of floristic composition of the region.

Studies on the vegetation of Al Baha region go back to the last two decades of the nineteenth century [24-25]. Moreover, Al-Aklabi, et al., [26] have tried to analyze the vegetation types of the region and come up with interesting reports about species composition and vegetation of the region. However, the studies were mainly focused along accessible roads and there are many important pocket points not covered in these studies. Moreover, in the presence of intense anthropogenic disturbance and climate changes; monitoring of vegetation changes over time is very important to assess the trends of species diversity, density, richness and associated contributing factors in the dynamics of plant community and species richness of the region. In this regard Tilman [14] and Vitousek et al., [27] reported the occurrences of declining of species diversity declining and the extinction acceleration of different species within many plant habitats as a result of human interferences.

The aim of the current study is to conduct the floristic composition of the target area through analyzing the density, frequency and diversity of plant species that existing in different land forms.

\section{Materials and Methods:-}

Study area:-

Al Baha region is located in the south west of Saudi Arabia, it is situated between 41/42 E and longitude and 19/20 $\mathrm{N}$ latitude. It is the smallest region among the 13 administration regions of the Kingdom of Saudi Arabia with an 
area of about $12,000 \mathrm{~km} 2$ representing almost 0.6 of the total land area of the country [28]. Climate is greatly affected by its varying geographic features, a high altitude mountains is greatly affected by fog. The current research is conducted in the high altitude area of Al Baha region, that covers about $920 \mathrm{~km} 2$ area (Fig. 1). The dominant plant communities of the study area are Juniperus procera and Acacia origena communities.

The study area climate is greatly affected by fog, because it is located at a high altitude mountain. The area temperature is relatively moderate with $22-32{ }^{\circ} \mathrm{C}$ in summer and $10-22{ }^{\circ} \mathrm{C}$ in winter. The average annual rainfall ranges between $229-581 \mathrm{~mm}[29-30]$.

According to Koppen's, [31], reported that the predominant climate of the Arabian Peninsula is dry and semiarid climates (Bwh). Al Baha the entire area almost belongs to the climate class of Bwh of tropical / subtropical desert [32]. The study area landscape consists of moderately to steep rocky slope mountain, wadis, rocky outcrops, terraces, fallow and cultivated fields. The altitude ranges between 1900 - $2475 \mathrm{~m}$ above sea level.

\section{Sampling Procedures:-}

The sampling procedures were carried out according to the method described by [9, 33-34]. A total of 73 sample plots $25 \mathrm{~m} \times 25 \mathrm{~m}$ were laid out in different land forms (Fig. 2). The land form types and plots number of plots laid out in each land form are rocky slope (36 plotes), wadi bed (18 plots), rocky outcrops (5 plots), follow land (7 plots), terraces ( 4 plots) and plains ( 3 plots). Within each plot, information on percentage of vegetation cover, number of each plant species, land form, species enumeration, were recorded. One voucher specimen was collected from each plant species and deposited at Al Baha University.

\section{Data analyze:-}

The collected data was entered_in to the excel sheet and subjected to different diversity indices such as:

\section{Density:-}

Number of individuals refers to the density of each species that has been recorded in the sample sites (quadrat $25 \mathrm{~m}$ $\times 25 \mathrm{~m}$ ) during the vegetation survey. The numbers of individuals in each site were calculated per hectare. This is achieved by dividing the total number of individuals by the total areas surveyed in the different land forms. Further using the Arc-GIS (ArcMap), the plant density was plotted along the study area (Fig. 3).

\section{Frequency:-}

Frequency was calculated by dividing the number of plots in which a species occurs into the total number of plots sampled.

$$
\text { Frequency }=\frac{\text { No. of plots with a species }}{\text { Total number of plots }}
$$

\section{Diversity:-}

Plant Species diversity was analysed using the following methods:

Shannon's diversity index, (Shannon and Weaver, 1949)

$$
H^{\prime}=\sum_{i=1}^{S} P i \ln (\mathrm{pi})
$$

Where pi is the proportion of individuals of species in the species

$$
D=\sum\left(\frac{n i(n i-1)}{N(N-1)}\right)
$$

Where, $\mathrm{ni}=$ the number of individuals in the $\mathrm{i}^{\text {th }}$ species, $\mathrm{N}$ the total number of individuals.

Evenness

$$
J^{\prime}=H^{\prime} / \ln s
$$

where, $H^{\prime}$ is the Shannon's diversity index

\section{Importance Value Index (IVI):-}

Importance values refer to how important a species is in terms of the structure of a community or species composition. To determine the importance of each species sampled, the importance value index (IVI) of each plant species was calculated in all study sites by summing the relative density value, the relative dominance value, and the relative frequency value [35-36]. These values are expressed in an absolute form and as relative density, relative 
dominance, and relative frequency, which shows the percentage of an individual species with respect to the total species. These values are calculated by the following equations:-

$$
\begin{aligned}
& \text { Relative density }=\frac{\text { Density (number of individuals)of a species }}{\text { total density for all species }} \times 100 \\
& \text { Relative dominance }=\frac{\text { Dominance for a species }}{\text { total dominance for all species }} \times 100 \\
& \text { Relative Frequency }=\frac{\text { Frequency value for a species }}{\text { total of frequency values for all species }} \times 100 \\
& (\text { IVI })=\text { relative density }+ \text { relative dominance }+ \text { relative frequency (8) }
\end{aligned}
$$

Table 1:- Major families with respective number of species and generas recorded in the study.

\begin{tabular}{|l|l|l|}
\hline family & Species & Genera \\
\hline Asteraceae (Compositae) & 32 & 23 \\
\hline Poaceae (Graminea) & 12 & 11 \\
\hline Lamiaceae (Labiatae) & 12 & 10 \\
\hline Apocynaceae (Asclepiadaceae) & 9 & 6 \\
\hline Solanaceae & 7 & 4 \\
\hline Chenopodiaceae & 6 & 3 \\
\hline Euphorbiaceae & 6 & 4 \\
\hline Malvaceae & 6 & 3 \\
\hline Fabaceae (Papilionoideae) & 5 & 2 \\
\hline Moraceae & 5 & 1 \\
\hline Mimosaceae & 5 & 2 \\
\hline Polygonaceae & 4 & \\
\hline Scrophulariaceae & 4 & 2 \\
\hline
\end{tabular}

Table 2:- Number of individuals per hectare for the most dominant species over the different landforms.

\begin{tabular}{|l|l|}
\hline density/ha & plant name \\
\hline 226 & Hyparrhenia hirta \\
\hline 176 & Achillea biebersteinii \\
\hline 167 & Cynodon dactylon \\
\hline 134 & Themeda triandra \\
\hline 116 & Juniperus procera \\
\hline \hline
\end{tabular}

Table 3:- The frequency of five most dominance plant species

\begin{tabular}{|l|l|}
\hline frequency & Plant name \\
\hline 0.86 & Juniperus procera \\
\hline 0.67 & Acacia origena \\
\hline 0.47 & Dodonaea viscosa \\
\hline 0.45 & Psiadia punctulata \\
\hline 0.44 & Sageretia thea \\
\hline
\end{tabular}

Table 4:- The comparative distribution of species and genera within the families

\begin{tabular}{|l|c|c|l|c|c|}
\hline Family & Species & Genera & Family & Species & Genera \\
\hline Asteraceae & 32 & 23 & Capparaceae & 1 & 1 \\
\hline Poaceae(Graminea) & 12 & 11 & Caryophyllaceae & 1 & 1 \\
\hline Lamiaceae & 12 & 10 & Celastraceae & 1 & 1 \\
\hline Apocynaceae & 9 & 6 & Convolvulaceae & 1 & 1 \\
\hline Solanaceae & 7 & 4 & Crassulaceae & 1 & 1 \\
\hline Chenopodiaceae & 6 & 3 & Cucurbitaceae & 1 & 1 \\
\hline Euphorbiaceae & 6 & 4 & Cupressaceae & 1 & 1 \\
\hline Malvaceae & 6 & 3 & Ebenaceae & 1 & 1 \\
\hline
\end{tabular}




\begin{tabular}{|l|l|l|l|l|l|}
\hline Fabaceae & 5 & 2 & Ephedraceae & 1 & 1 \\
\hline Moraceae & 5 & 1 & Ericaceae & 1 & 1 \\
\hline Mimosaceae & 4 & 2 & Juncaceae & 1 & 1 \\
\hline Polygonaceae & 4 & 2 & Loranthaceae & 1 & 1 \\
\hline Scrophulariaceae & 4 & 4 & Myrtaceae & 1 & 1 \\
\hline Amaranthaceae & 3 & 3 & Oxalidaceae & 1 & 1 \\
\hline Anacardiaceae & 3 & 2 & Papaveraceae & 1 & 1 \\
\hline Boraginaceae & 3 & 3 & Plantaginaceae & 1 & 1 \\
\hline Brassicaceae (Cruciferae) & 3 & 3 & Polygalaceae & 1 & 1 \\
\hline Geraniaceae & 3 & 3 & Portulacaceae & 1 & 1 \\
\hline Nyctaginaceae & 3 & 3 & Primulaceae & 1 & 1 \\
\hline Oleaceae & 3 & 2 & Ranunculaceae & 1 & 1 \\
\hline Rhamnaceae & 3 & 3 & Rosaceae & 1 & 1 \\
\hline Zygophyllaceae & 3 & 2 & Rubiaceae & 1 & 1 \\
\hline Acanthaceae & 2 & 2 & Rutaceae & 1 & 1 \\
\hline Loganiaceae & 2 & 2 & Salicaceae & 1 & 1 \\
\hline Resedaceae & 2 & 2 & Santalaceae & 1 & 1 \\
\hline Adiantaceae & 1 & 1 & Sapindaceae & 1 & 1 \\
\hline Aizoaceae & 1 & 1 & Tamaricaceae & 1 & 1 \\
\hline Aloeaceae & 1 & 1 & Tiliaceae & 1 & 1 \\
\hline Apiaceae (Umbelliferae) & 1 & 1 & Typhaceae & 1 & 1 \\
\hline Asparagaceae & 1 & 1 & Ulmaceae & 1 & 1 \\
\hline Asphodelaceae & 1 & 1 & Urticaceae & 1 & 1 \\
\hline Barbeyaceae & 1 & 1 & Verbenaceae & 1 & 1 \\
\hline Cactaceae & 1 & 1 & & & \\
\hline Caesalpiniaceae & 1 & 1 & & & \\
\hline & & & & & 1 \\
\hline
\end{tabular}

Table 6:- Importance Value Index of most dominant plant species of the study area.

\begin{tabular}{|l|c|c|c|c|}
\hline Scientific name & $\begin{array}{l}\text { Relative } \\
\text { dominance }\end{array}$ & $\begin{array}{l}\text { relative } \\
\text { frequency }\end{array}$ & $\begin{array}{l}\text { Relative } \\
\text { density }\end{array}$ & Importance Value Index (IVI) \\
\hline Juniperus procera & 15.26 & 5.09 & 4.77 & 25.1 \\
\hline Hyparrhenia hirta & 4.95 & 2.34 & 9.27 & 16.6 \\
\hline Acacia origena & 8.71 & 3.96 & 2.72 & 15.4 \\
\hline Achillea biebersteinii & 3.85 & 1.29 & 7.22 & 12.4 \\
\hline Themeda triandra & 2.93 & 2.50 & 5.49 & 8.9 \\
\hline Eragrostis spec. & 2.34 & 1.78 & 4.38 & 8.0 \\
\hline Dodonaea viscosa & 3.22 & 2.74 & 2.01 & 7.2 \\
\hline Maytenus parviflora & 3.38 & 2.50 & 1.32 & 6.7 \\
\hline Psiadia punctulata & 2.29 & 2.66 & 1.79 & 6.5 \\
\hline Tripteris vaillantii & 1.56 & 2.02 & 2.92 & 6.4 \\
\hline Olea europaea & 2.96 & 2.50 & 0.93 & 6.1 \\
\hline Onopordum heteracanthum & 2.64 & 1.78 & 1.65 & 5.6 \\
\hline Sageretia thea & 2.14 & 2.58 & 0.84 & 5.3 \\
\hline Halothamnus bottae & 1.38 & 1.29 & 2.59 & 5.1 \\
\hline Andropogon sp. & 1.39 & 1.13 & 2.61 & 5.0 \\
\hline Marrubium vulgare & 1.47 & 0.81 & 2.76 & 4.5 \\
\hline Rumex nervosus & 1.85 & 1.53 & 1.16 & 4.4 \\
\hline Asphodelus fistulosus & 0.95 & 1.61 & 1.79 & 4.3 \\
\hline Cenchrus ciliaris & 1.28 & 0.65 & 2.40 & 4.3 \\
\hline Aristida adscensionis & 0.97 & 1.53 & 1.82 & 4.2 \\
\hline Pulicaria undulata & 0.72 & 2.18 & 1.34 & 4.1 \\
\hline Echinops sp & 1.00 & 1.21 & 1.87 & 3.9 \\
\hline Acacia gerrardii & 1.90 & 1.37 & 0.59 & 3.9 \\
\hline Solanum incanum & 0.47 & 2.50 & 0.88 & \\
\hline
\end{tabular}




\begin{tabular}{|l|c|c|c|c|}
\hline Nicotiana glauca & 1.18 & 1.53 & 0.74 & 3.4 \\
\hline Lavandula pubescens & 0.63 & 1.29 & 1.19 & 3.1 \\
\hline Periploca aphylla & 1.01 & 1.61 & 0.40 & 3.0 \\
\hline Lavandula dentate & 0.47 & 1.45 & 0.87 & 2.8 \\
\hline Ficus palmata & 0.80 & 1.05 & 0.25 & 2.1 \\
\hline
\end{tabular}

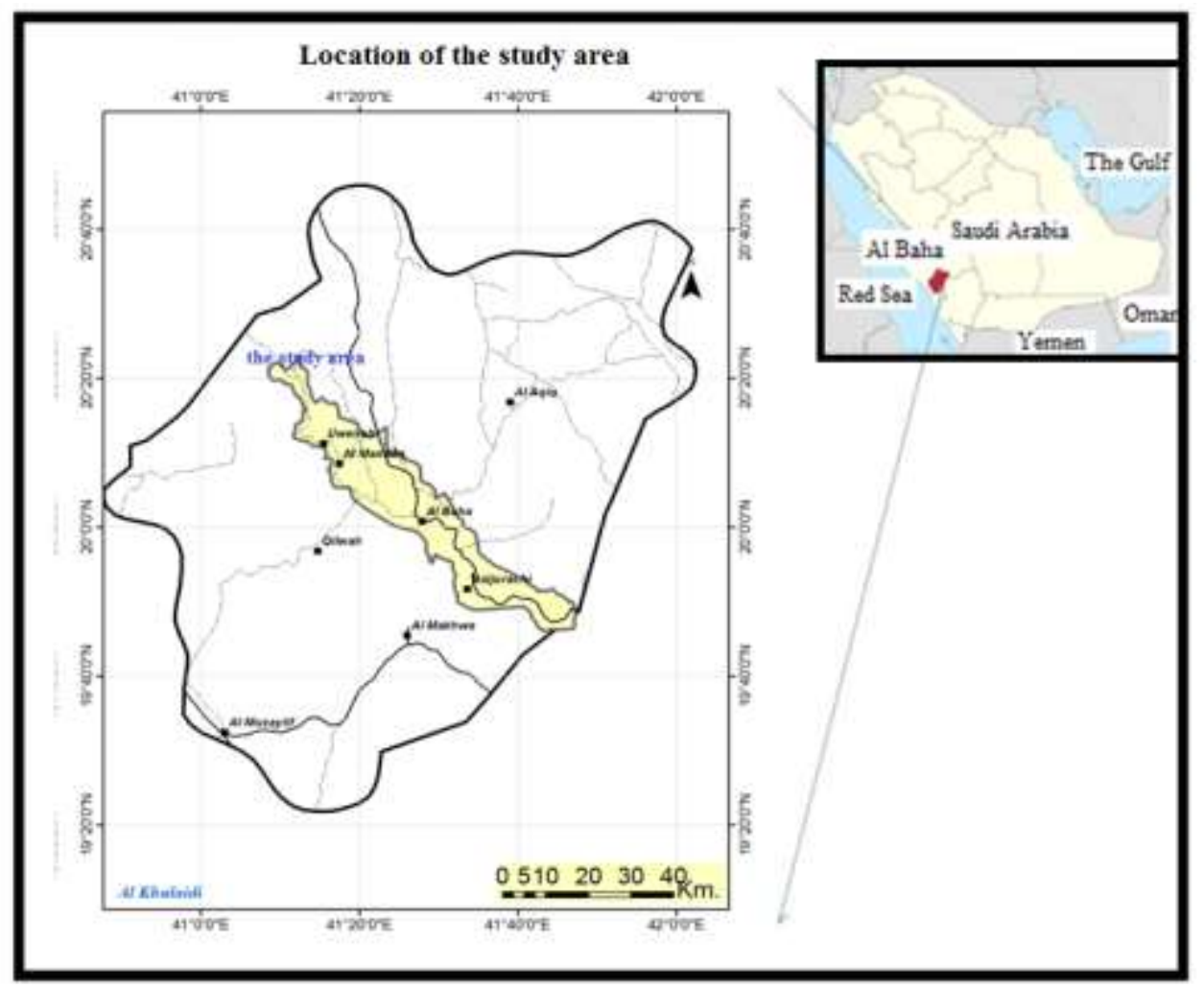

Fig. 1:- The map of the study area 


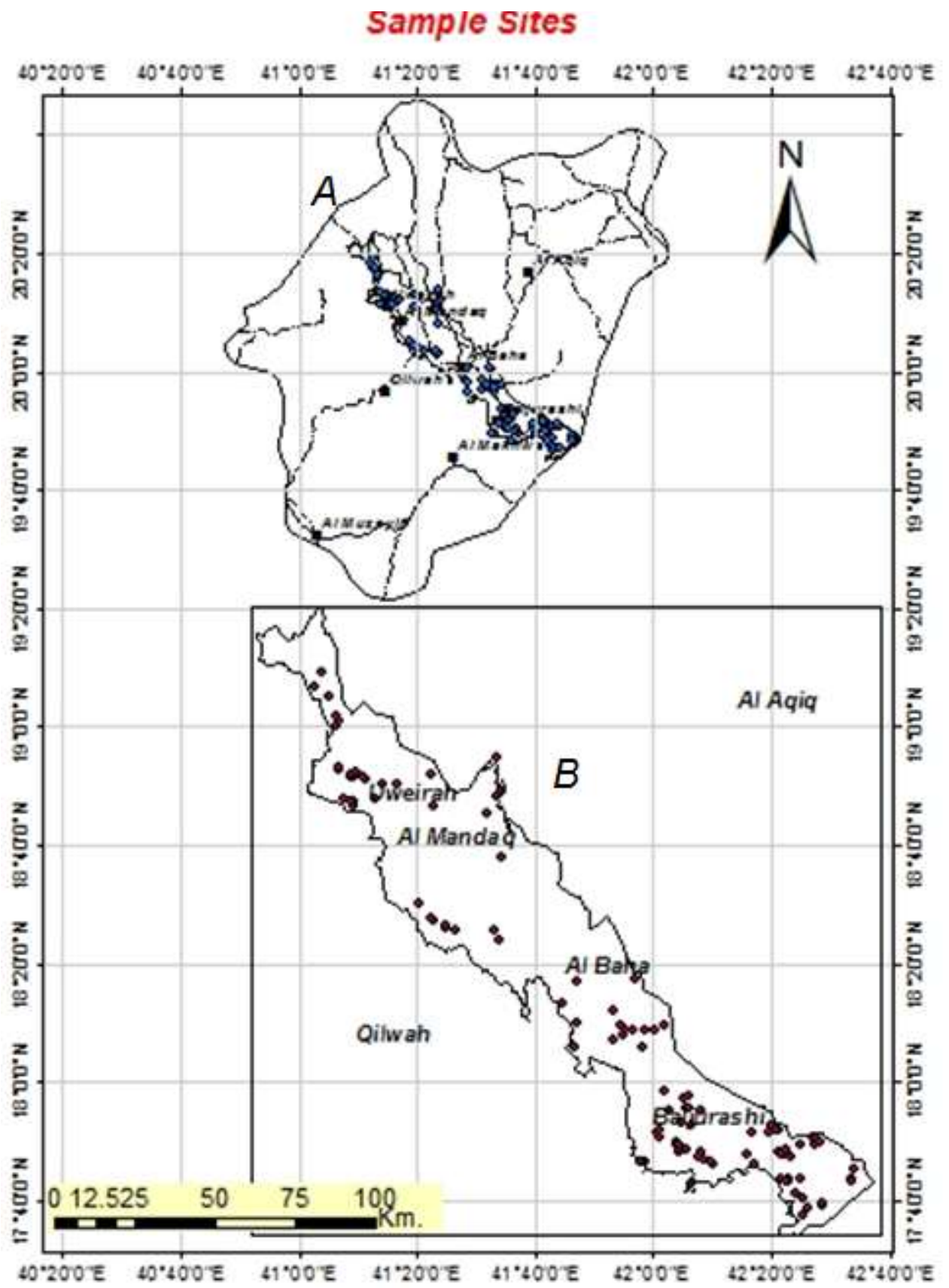

Fig. 2:- The locations of sample sites (Plots) over the study area. A = Map of Albaha region, B = map of the study are. 


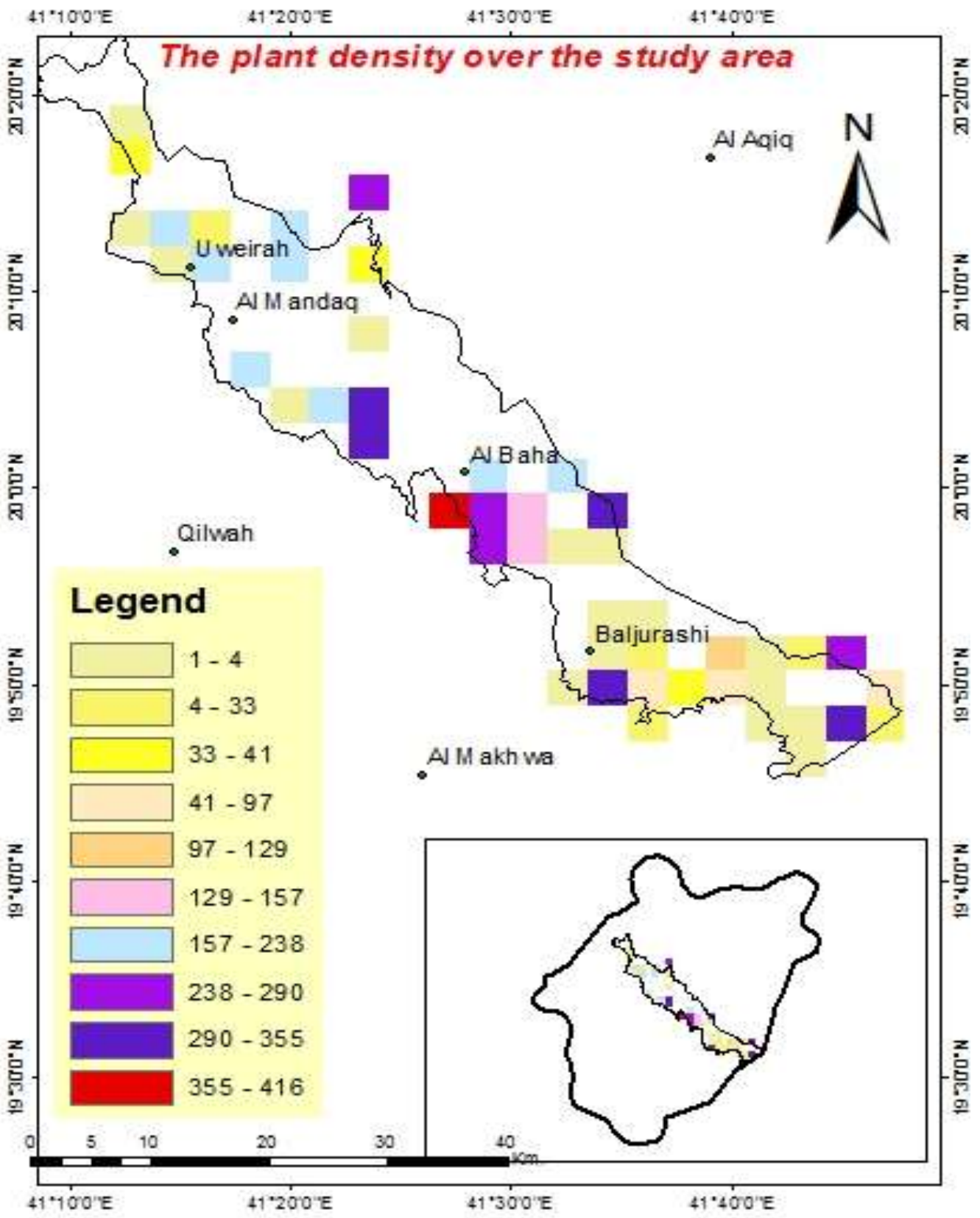

Fig. 3:- The plant density over the study area 


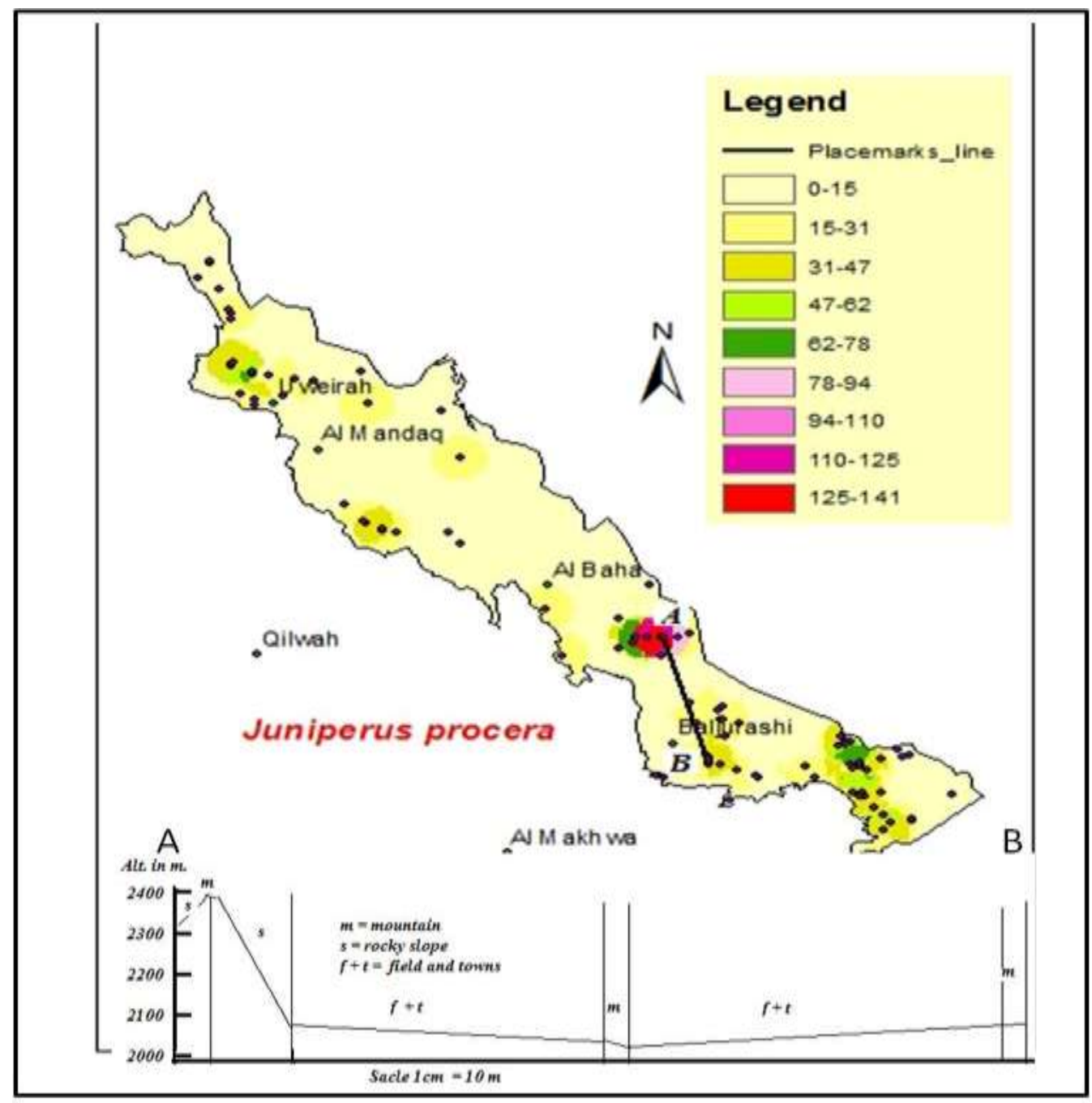

Figure 4:- A map showing the density of Juniperus procera in the study area, the cross section from A to B shows that Juniperus procera was abundant on the mountain and rocky slope areas but it was absent or existed in a small number on the almost flat fields, near towns and wadis. 


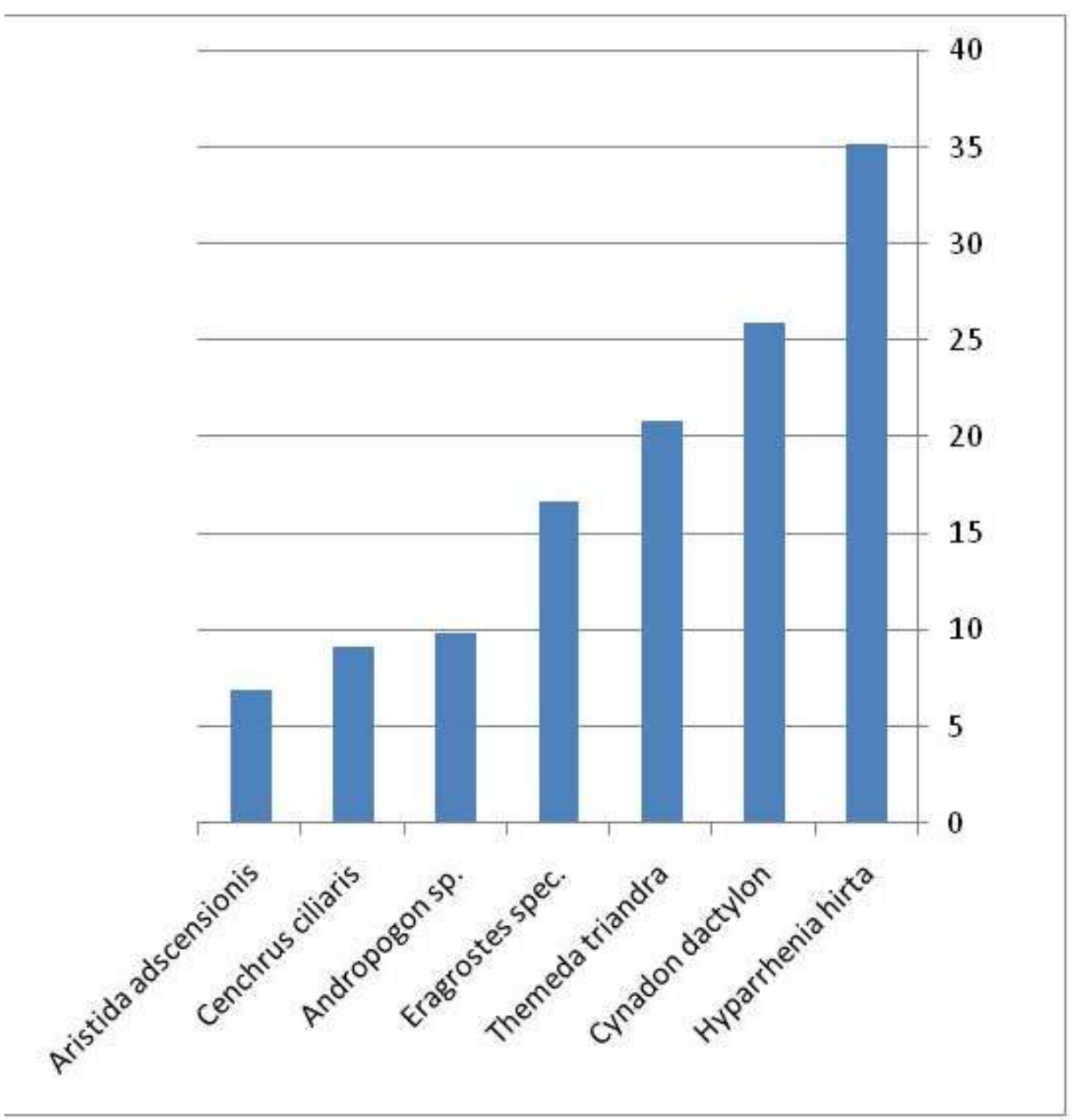

Figure 5:- The Relative density of grass

\section{Results and discussion:-}

Floristic analysis:-

A total of 185 plant species belonging to 147 genera and 67 families are recorded in all land forms, in which 3 are endemic to Arabian Peninsula and one is endemic to Saudi Arabia. The data on distribution of genera and species among the families revealed that, the top five dominant families are Asteraceae with 23 genera and 32 species, followed by Poaceae (Graminea) with 11 genera and 12 species, Lamiaceae with 10 genera and 12 species, Apocynaceae with 6 genera and 9 species and Solanaceae with 4 genera and 7 species while the rest ranges from 1 4 genera with $4-6$ species (Table 1). There are also 42 families represented by only by one plant species and 3 families by only 2 plant species.

The following plant species are considered rare in the study area, because they were only recorded once: Acacia ehrenbergiana, Achyranthes aspera, Capparis cartilaginea, Monolluma quadrangula (= Caralluma quadrangula), Ceratonia siliqua, Citrullus colocynthis, Conyza incana, Ehretia obtusifolia, Euclea racemosa, Felicia dentate, Ficus carica, F. ingens, F. sycomorus, Foeniculum vulgare, Lavandula cronopifolia, Lycium shawii, Meriandra bengalensis, Nuxia oppositifolia, Osyris quadripartita, Pentas lanceolata, Plectranthus asirensis.

Few species are weedy and are found in large quantities in rainy seasons, especially in wet areas or near cultivated and fallow lands. These are Calendula arvensis, Erodium cicutarium, Aizoon canariensis and Anagallis arvensis.

The species named Acacia origena, Asphodelus fistulosus, Dodonaea viscosa, Juniperus procera, Maytenus parviflora, Nicotiana glauca, Olea europaea, Psiadia punctulata, Pulicaria undulata, Rumex nervosus, Sageretia thea, Solanum incanum and Themeda triandra exist throughout the entire area, in particular on the mountain slopes, 
Nicotiana glauca has recently invaded the study area. Onopordum heteracanthum, Achillea biebersteinii, Tripteris vaillantii are widespread species in wad beds, roadsides and fallow lands.

\section{Plant density:-}

The number of individuals per hectare (Table 2) is calculated by dividing the total number of individuals into the total areas for each site as surveyed over the different landforms. Accordingly, the most dominant species are listed in table 2 .

Variations in number of individuals are observed in the study area. Also some species exist at high numbers in one landform and at low numbers or are absent in other landforms. For example, the number of individuals of Acacia origena, Asphodelus fistulosus and Echinops $s p$ were high in relatively flat wadi beds and fallow lands and low or absent on rocky slopes, while Juniperus procera, Themeda triandra and Hyparrhenia hirta were high on the rocky slopes and low on fallow land and wadis. The plant density was plotted along the study area using Arc Map application (Fig. 3)

\section{Plant frequency:-}

Table 3 shows the frequency for the most abundant species in the study area. Variations in abundance can also be observed. Some species exist at high frequencies in one landform and at low frequencies or absent in other landforms.

Juniperus procera was one of the most abundant species recorded in the study area. It has mean frequency of 0.86 , but it is absent or existed at very often on the flat fallow lands, fields and wadis (Fig. 4). Acacia origena, Dodonaea viscosa, Psiadia punctulata and Sageretia thea were widespread species (Table 3), with a considerable variation in abundance from one landform to another. The frequency of Acacia origena was high in the fallow lands and at times formed woodland, while Juniperus procera was high in rocky mountains and low in fallow lands and wadis.

\section{Floristic diversity:-}

A total of 187 plant species belonging to 147 genera and 67 families are recorded in all land forms. The distribution of genera and species among the families wise revealed.

The average number of plant species per sample plots was 2.6 species. The highest number of species was 41 and the lowest was 6 . Many species were present only in one or very few samples per plot. Out of 187 plant species, only $10(5 \%)$ were present in more than $40 \%$ of the sample plots. These species are: Juniperus procera, Acacia origena, Dodonaea viscosa, Psiadia punctulata, Sageretia thea, Themeda triandra, Olea europaea, Maytenus parviflora, Solanum incanum and Hyparrhenia hirta. The comparative distribution of species and genera within the families is given in Table 4 .

The calculation of plant diversity using numbers of individuals for each plant species was achieved by using Shannon index. The use of presence and absence data failed to give logical results, for example the evenness values for all areas were 1 .

The Shannon index takes into consideration the relative contribution of all species. The more the abundance is equitably distributed among species, the higher the value of diversity [37].

Shannon's diversity index shows that the sample sites 130 (wadi), 247 (rocky slope), 253 (wadi), 159 (wadi), 262 (wadi), 242 (terraces), 24 (rocky outcrop), 235 (rocky outcrop), 16 (rock outcrop), and 156 (rocky outcrop), were more diverse than the other sample sites. The Shannon index is calculated as 2.905 for site 130, 2.84 for site 247, and 2.778 for site 253. Many diverse sample sites are located on wadis tand sites with rocky outcrops, which support a habitats characterized by relatively deep and moist soil.

As can be seen, site 235 of rocky outcrops has more species than site 247 of rocky slope and 253 of wadi. However, Shannon's diversity indices show that sites 247 and 253 are more diverse. This is because the total number of individuals in sites 247 and 253 are almost equally distributed between the most plant species.

Importance Value Index (IVI) :-

Importance values refer to how important a species is in terms of community structure of a community or species 
composition [36, 38]. To determine the importance of each species sampled, the importance value index (IVI) of each plant species was calculated by summing the relative density value, the relative dominance value, and the relative frequency value $[35,36]$ (see Table 6). The dominant tree species that represent the woodland and forest structure area are Juniperus procera, Acacia origena and Olea europaea.

As can be observed, from Table 5 few species have more importance value than other species and most of the Importance Values are distributed among just a few species; notably Juniperus procera, Acacia origena, Hyparrhenia hirta, Achillea biebersteinii and Themeda triandra. These species are widely distributed over the entire study area in particular on the mountain slopes and the plateau. Table 6 shows the most importance plant species of the study area.

The study area is a biodiversity conservation unit typified for its richness and diversity in flora. The richness in biodiversity makes it a gene bank for most species in particular forage grass species. The flora of the study area is characterized by a variety of plant species. The Asteraceae, Poaceae, and Lamiaceae were observed to be the most prevalent family. This may be due to their fast germination ability, associated with favourable environmental conditions which have enabled species to produce numerous seeds which was eventually established at suitable sites easily. These families are also considered the largest natural plant families distributed all over the globe wherever vegetation is found and most of it species is well adapted to the wet and high altitude plateau. This finding was in line with Collenette, [39] which reported that the family of Asteraceae has the highest plant species in Saudi Arabia. Wood, [40] and Al-Khulaidi [6] also reported that the Asteraceae and Poaceae (Graminea) were the most important families of Yemen's flora.

Juniperus procera, Acacia origena, Hyparrhenia hirta, Achillea biebersteinii and Themeda triandra are the most important plant species in the study area. Themeda triandra can tolerate light to moderate grazing and is considered among the most productive grasslands in the world [41]. Hyparrhenia hirta is higher in quality pastures and common in southern Africa and exists throughout Africa to the Mediterranean region, Middle East, Arabia and Pakistan [42-43].

Generally, species diversity is one of the most important indices used to evaluate an ecosystem. A rich ecosystem with high species diversity has a large value while an ecosystem with low value will have low species diversity [4445]. The present study site had a high species diversity grass.

The Species richness of rocky slopes and wadis could be attributed to rich organic content and mineral resources utilized by the species for growth and production. Giliba et al [46] reported similar findings on woodland of Bereku Forest Reserve in Tanzania. Juniperus procera is the dominant tree species, and is considered by the IUCN as Least Concern ver 3.1 species [47]. Juniperus procera forms evergreen Afromontane forest that exists on different ecological sites of north eastern, eastern, west-central, and south tropical Africa [48]. Juniperus procera is also abundant between 1400 and $2500 \mathrm{~m}$ in the south-western Arabia (Saudi Arabia and Yemen) in particular at the slope facing west (Fog-affected Area) [6, 40, 43, 49].

The Relative density of grassland ecosystem of the study area, Hyparrhenia hirta, Cynodon dactylon and Themeda triandra make up about 75 percent of the density cover (Fig.5). Cynodon dactylon mainly found on fallow lands and wet sites.

Hyparrhenia hirta exists in grassland, rocky places and open woodland, in southern Africa mostly in upland dambos. It is found from the shores of the Mediterranean sea up to $2600 \mathrm{~m}$ in East Africa. It grows satisfactorily with an annual rainfall of $500 \mathrm{~mm}$ or more, In South Africa. Hyparrhenia hirta, often together with Themeda triandra, dominates several of the tall-grass- veld vegetation types, particularly in disturbed veld [50], Hyparrhenia grassland type of grassland found [51] in open steep and wooded grassland vegetation or flooded valleys in the higher rainfall areas of Kenya, Ethiopia, Tanzania, Somalia and Uganda [41]. Hyparrhenia spp. and Themeda triandra provide late-season grazing for livestock [51] but have low palatability [52].

Acacia origena is found near or on cultivated fields in wadis, terraces, plains and plateaus or mountain slopes of high altitude areas (between 1600 and 2800 m.) of Yemen (e.g. Ibb, NE At Turba, Jabal Saber, Jabal Sumara, Utuma), The woodland dominated by Acacia origena with Themeda triandra, Hyparrhenia hirta, is found on mountain slopes and terraces between 1950 - $2250 \mathrm{~m}$ [6]. 
The numbers of sample plots are not equal in different land forms for the reason that some land form such as wadis and fallow lands showed no increase in species richness with increasing number of plots. That means there is homogeneity in species composition in the land form and there is not extra species recorded in the site.

The flora of the study area is a mixture of the tropical African, Sudanian plant geographical region (Paleotropical origin) and the Mediterranean regions or Afromontane archipelago-like regional centre of endemism, with very few Saharo-Sindian or Saharo-Arabian region (Holarctic origin).

According to White [53], Ramdhani et al [54], the study area lies on the Afromontane archipelago-like regional centre of endemism. According to Zohary [55], the study area falls within Sudanian-region. Most of the Mediterranean and Sahro-Arabian elements are found in the main wadis swhile most of the Sudanian-region elements are found on the mountain slopes.

The Paleotropical origin species include: Acacia gerrardii, Andropogon sp., Asparagus africanus, Buddleja polystachya, Celtis africana, Clutia lanceolata, Felicia dentate, Ficus carica, Ficus cordata, Ficus ingens, Ficus palmata, Ficus sycomorus, Forsskaolea tenacissima, Hypoestes forskalei, Indigofera spinosa, Jasminum grandiflorum, Maytenus parviflora. Olea europaea, Tamarix nilotica, Withania somnifera, Ziziphus spina-christi

The Mediterranean elements species include: Ammi majus, Anagyris foetida, Anarrhinum forsskaolii, Asphodelus fistulosus, Capparis cartilaginea, Ceratonia siliqua, Ephedra aphylla, Juniperus procera, Lavandula cronopifolia, Lavandula dentate, Lavandula pubescens, Marrubium vulgare, Nuxia oppositifolia, Rumex nervosus, Rumex steudelii, Rumex vesicarius, Salvia aegyptiaca, Solanum schimperianum, Teucrium yemense.

Saharo-Sindian or Saharo-Arabian regions (Holarctic origin) are: Astragalus atropilosulus. Cymbopogon sp., Ochradenus baccatus, Periploca aphylla, Pulicaria undulate and Tribulus terrestris.

A few species of Sahara-Sahel linking element [53] are found in the region, these are: Blepharis edulis, Forsskaolea tenacissima,

Outside Arabia there are few species that are only found in Africa (regional endemic) such as Sudan, Somalia, Ethiopia, Eretria and Kenya) for example: Acacia origena, Pistacia falcata, Pluchea dioscorides, Psiadia punctulata, Rhus retinorrhoea.

\section{Conclusion:-}

The dominant vegetation structure in the study area is a woodland dominated by Juniperus procera and Acacia origena and grassland dominated by Hyparrhenia hirta and, Themeda triandra. Average tree cover is $25 \%$, shrub cover is $17 \%$ and herbaceous cover is $36 \%$ with an average of $77 \%$ vegetation cover.

This study revealed that the Al Baha high land has high species diversity dominated by Juniperus procera, Hyparrhenia hirta and Acacia origena. Families noted with high number of species in the study area included: Asteraceae, Poaceae, and Lamiaceae. Species richness for some areas was very poor due to over grazing and intensive human activities. Nevertheless, still few sites with high species diversity due to effective conservation and sustainable management of were observed.

The survey showed that the woodlands in many sites are dominated by small sized trees, poor shrub species with high grasses density, indicating that the woodlands were heavily exploited and affected in the previous periods. Good regeneration is in process at the few protected sites. Therefore, to improve the natural diversity and structure of the Juniperus procera woodlands, to minimize the influence of the Municipal and surrounding communities pressures and utilize the woodland resources sustainably for present and future generation, the basic needs and traditional rights of Municipal and the communities over the uses of woodland resources and woodland areas should be recognized.

\section{Acknowledgements:-}

The researchers would like to express their thanks to the director of University of Al Baha and the Dean of College of Science and Arts, Baljurashi, Al Baha University (BU), for their great help and assistance to fulfil this study. 


\section{Reference:-}

1. Chaudhary S.A., Al-Juwaid, A.A (1999). Vegetation of the Kingdom of Saudi Arabia. National Agriculture Research Center, Ministry of Agriculture \& Water, P.O. 17285, Riyadh-11484. Saudi Arabia.

2. Chaudhary S.A (2010). Destructions of Acacia woodlands and Juniper forests in Asia and Eastern Africa.. Pak. J. Bot., Special Issue (S.I. Ali Festschrift) 42: 259-266.

3. El-Juhany L (2015). The Magnitude of Dieback on Juniperus procera Trees in the Natural Forests in the Southwestern Region of Saudi Arabia. Biosciences Biotechnology Research Asia. 12: 219-230

4. Andrew S.G., Fisher, M (1996). The Distribution and Status of the Montane Juniper Woodlands of Oman. Journal of Biogeography. 23: 791-803

5. Kurschner, H (1998). Biogeography and introduction to vegetation. In: Ghzanfar SA, Fisher M. (eds) Vegetation of the Arabian Peninsula. Kluwer, Dordrecht.

6. Al-Khulaidi, A, A., 2013. Flora of Yemen. The Sustainable Natural Resource Management Project (SNRMP II). EPA and UNDP, Republic of Yemen.

7. Brown J (2001). Mammals on mountainsides: elevational patterns of diversity. Global Ecology and Biogeography. 10:101-109.

8. Lomolino M.V (2001). Elevation gradients of species-density: historical and prospective views. Global Ecology and Biogeography 10:3-13.

9. Mueller-Dombois D., Ellenberg H (1974). Aims and methods of vegetation ecology. John Wiley and Sons, New York. pp 547.

10. Daubenmire R.F (1968). Plant communities: A textbook of plant synecology. Harper and Row, New York.300 pp.

11. Greig-Smith, P (1983). Quantitative plant ecology. 3rd ed. Blackwell Sci. Publ., Oxford.359 pp.

12. Al-Khulaidi A. A., Miller A., Furley P (2010). Environmental and human determinates of vegetation distribution in the Hadhramaut region, Republic of Yemen. LAMBERT Academic publishing Saarbrucken, Grmany. PP 420.

13. Wilsey B. J, Potvin, C (2000). Biodiversity and ecosystem functioning: the importance of species evenness in an old field. Ecology 81: 887-892.

14. Tilman T.D (2000). Causes, consequences and ethics of biodiversity. Nature 405: 208- 211.

15. Rahbek C (1995). The elevation al gradient of species richness: a uniform pattern? Ecography 18: 200-205.

16. Austrheim G (2002). Plant diversity patterns in semi-natural grasslands along an elevational gradient in Southern Norway. Plant Ecology. 161:193-205

17. Vetaas O.R., Gerytnes J.A (2002). Distribution of vascular plant species richness and endemic richness along the Himalayan elevation gradient in Nepal. Global Ecology and Biogeography. 11: 291-301.

18. Sanders N.J., Moss J., Wagner D (2003).Patterns of ant species richness along elevational gradients in an arid ecosystem. Global Ecology and Biogeography. 10: 77-100.

19. Tilman D., Downing, J.A (1994). Biodiversity and stability in grasslands. Nature 367: 363-365.

20. Grytnes J.A (2003). Species-richness patterns of vascular plants along seven altitudinal transects in Norway. Ecography. 26: 291-300.

21. Kessler M (2000). Elevational gradients in species richness and endemism of selected plant groups in the central Bolivian Andes. Plant Ecol. 149:181-93

22. Oommen M.A., Shanker K (2005). Elevational species richness patterns emerge from multiple local mechanisms in Himalayan woody plants. Ecology 86:3039-47.

23. Qian H., White P.S., Song J.S (2007). Effects of regional vs. ecological factors on plant species richness: an intercontinental analysis. Ecology 88:1440-53

24. Zayed K.M., Fayed A.A (1987). Vegetation of area between Taif and Baha, SW Saudi Arabia, Taeckholmia 10: 77-105.

25. El-Karemy, Z.R., Zayed, K.M (1996). A contribution to the vegetation and habitat types of Baha plateau (Saudi Arabia). Feddes Repertorium. 107: 135-144.

26. Al Aklabi A., Al Khulaidi A.W., Hussain A., and Al Sagheer N (2016). Main vegetation types and plant species diversity along an altitudinal gradient of Al Baha region, Saudi Arabia. Saudi Journal of Biological Sciences

27. Vitousek P. M., Lubchenco A. J, Melillo, J. M (1997). Human domination of earth's ecosystems. Science 277: 494-499.

28. Saudi Geological Survey, 2012. Kingdom of Saudi Arabia: Facts and Numbers. First Edition, pp: 116. Saudi Geological Survey. www.sgs.org.sa

29. Ibrahim M. M (2010). Study of cystic echinococcosis in slaughtered animals in Al Baha region, Saudi Arabia: Interaction between some biotic and abiotic factors. Acta Tropica. 113: 26-33. 
30. Aref I. M., El-Atta H. A., AL-Ghamde, A.M (2011). Effect of forest fires on tree diversity and some soil properties International Journal of Agriculture and Biology.13: 659-664.

31. Koppen W (1936). Das geographische System der Klimate. In: Koppen W. Geiger R (eds) Handbuch der Klimatologle. Band 1.Teil V. Berlin.

32. Ayele T., AlShadily S. A (2000). Some of the Engineering Geological and Hydrogeological Problems and Conditions of Ethiopia and Yemen. Acta Geologica Universitatis Comenianae. 55:51- 62.

33. Synnott T. J (1979). A manual of permanent plot procedures for tropical rainforests". Tropical forestry papers Commonwealth forestry institute, University of Oxfored, No $10 \mathrm{p} 45$

34. Larpkern P., Moe S. R, Totland O (2009). The effect of environmental variables and human disturbance on woody species richness and diversity in a bamboo-deciduous forest in north eastern Thailand. Ecological Research, 24,147-156

35. Mahdi A., Al-Khulaidi A. A (1999). Vegetation degradation of mountain at Taiz, Yemen. Journal of Dalta 1: 75-95.

36. Nautiyal B. P., Chauhan R. S., Prakash V., Purohit H., Nautiyal M.C (2003). Population studies for the evaluation of germplasm and threat status of the alpine medicinal herb, Nardostachys jatamansi. Plant Genetic Resources IPGRI-FAO 136:34-39.

37. Kutiel P., Kutiel H., Lavee H (2000). Vegetation response to possible scenarios of rainfall variations along a Mediterranean-extreme arid climate transect. Journal of Arid Environments 44: 277-290.

38. Al Khulaidi A. A (2006). Environmental and human determinates of vegetation distribution in the Hadhramaut region, Republic of Yemen. A thesis submitted for the degree of Doctor of Philosophy School of GeoSciences University of Edinburgh. This study is published also in 2010 by LAMBERT, Acadimic Publishing. Berlin, German

39. Collenette S (1985). An illustrated guide to the Flowers of Saudi Arabia. Scorpion Publishing Ltd. London, 26.

40. Wood J. R (1997). A Handbook of the Yemen Flora. Royal Botanic Gardens, Kew. UK. pp 434.

41. Herlocker D (1999). Rangeland ecology and resource development in Eastern Africa. GTZ, Nairobi, Kenya.

42. Gibbs Russell G. E., Watson L., Koekemoer S. M., Barker N.P., Anderson H.M., Dallwitz, M. J (1990). Grasses of southern Africa. Memoirs of the Botanical Survey of South Africa No. 58.

43. Miller A. G., Cope T. A (1996). Flora of the Arabian Peninsula and Socotra. vol.1, EUP, UK, pp 586.

44. Sobuj N. A., Rahman M (2011) Assessment of plant diversity in Khadimnagar National Park of Bangladesh Inter. J. Environ. Sci. 2(1):1-13.

45. Deka J.T., Khan L.P (2012). High Dominance of Shorea robusta Gaertn. In Alluvial Plain Kamrup Sal Forest of Assam. N. E. India Int. J. Ecosys. 2: 67-73

46. Giliba R. A., Boon E. K., Musamba E. M., Kashindye A. M., Shayo P. F (2011). Composition, Richness and Diversity in Miombo. J. Biodiver. 2: 1-7.

47. IUCN (2013). IUCN Red List of Threatened Species (ver. 2013.1).

48. Adams R.P (2008). Juniperus of Canada and the United States: taxonomy, key and distribution. Phytologia, 90: 255-314.

49. Al-Khalili A. D., Nader I. A (1984). Nature conservation in Saudi Arabia: An ecological study of the Asir national park with a checklist of the terrestrial vertebrate fauna of the park and its surroundings. Fauna of Saudi Arabia 6: 11-31.

50. Clayton W.D., Renvoize S. A (1982).Graminea (part 3). In: Polhill R. M. (Editor). Flora of Tropical East Africa.A.A. Balkema, Rotterdam, Netherlands. pp. 451-898.

51. Rattray, J.M., 1960. The grass cover of Africa. FAO, Rome, Italy.

52. Skerman P. J., Riveros F (1990). Tropical grasses. FAO Plant Production and Protection Series, No. 23.832 p. FAO, Rome, Italy.

53. White F (1983). The vegetation of Africa. A descriptive memoir to accompany the Unesco/ Aetfat/ UNSO vegetation map of Africa. UNESCO, Paris.

54. Ramdhani S, Barker N.P., Baijnath F (2008). Exploring the Afromontane centre of endemism: Kniphofia Moench (Asphodelaceae) as a floristic indicator. Journal of Biogeography ( Biogeogr) 35, 2258-2273

55. Zohary M (1973). Geobotanical foundations of the Middle East.Gustav Fischer Verlagvolum 1\&2, Stuttgart, W. Germany. 